\title{
STRATEGI PENGEMBANGAN USAHATANI BAWANG MERAH DI DESA SAJEN, KECAMATAN PACET, KABUPATEN MOJOKERTO
}

\author{
Oleh : Didit Darmawan
}

Universitas Mayjen Sungkono Mojokerto

\begin{abstract}
The study was conducted in Sajen Village, Pacet District, Mojokerto Regency. The purpose of this study was to describe and analyze the strategy of developing farming to improve the welfare of the onion farmers in that area. In the Data Collection Phase, use the IFAS and EFAS matrices. The next stage, namely the Analysis Phase, is to collect all information that affects the development of the business. Next is to place the information gathered into the strategy formulation model, namely the SWOT matrix in internal and external factors, then the appropriate results are determined. In the final stage, use the SWOT Matrix. From the IFAS and EFAS Matrix, the value of $x$ is 0.49 and the value of $y$ is 0.57. The strategy of developing shallot farming in Sajen village is in quadrant I, meaning that onion has strength factors in good conditions but onion farmers have not taken advantage of the opportunities that exist so that onion has not yet developed. For this reason, aggressive strategy is needed, namely expanding and maximizing growth by utilizing existing opportunities and strengths (strength-opportunities strategy).
\end{abstract}

Keywords: strategy, farming, Allium cepa var oggregatum Sin Allium ascalonicum, SWOT

\begin{abstract}
ABSTRAK
Penelitian dilakukan di Desa Sajen, Kecamatan Pacet, Kabupaten Mojokerto. Tujuan Penelitian ini adalah mendeskripsikan serta menganalisis strategi pengembangan usahatani untuk meningkatkan kesejahteraan petani bawang merah di tersebut. Pada Tahap Pengumpulan Data menggunakan matriks IFAS dan EFAS. Tahap selanjutnya yakni Tahap Analisis yaitu mengumpulkan semua informasi yang berpengaruh terhadap pengembangan usahtani., Selanjutnya adalah menempatkan informasi yang terkumpul ke model perumusan strategi yaitu matriks SWOT dalam faktor internal dan eksternal kemudian dari hasil yang ada ditentukan pengambilan keputusan yang tepat. Pada tahap akhir yaitu menggunakan Matriks SWOT. Dari Matriks IFAS dan EFAS diketahui nilai x adalah 0,49 dan nilai y adalah 0,57. Strategi pengembangan usahatani bawang merah di desa Sajen berada di kuadran I, artinya bawang merah tersebut memiliki faktor-faktor kekuatan dalam kondisi yang baik namun petani bawang merah belum memanfaatkan peluang yang ada sehingga bawang merah belum berkembang. Untuk itu diperlukan sterategi agresif yaitu melakukan ekspansi dan meningkatkan pertumbuhan secara maksimal dengan memanfaatkan peluang dan kekuatan yang ada (strength-opportunities strategy).
\end{abstract}

Kata Kunci : strategi, usahatani, bawang merah, SWOT

\section{PENDAHULUAN}

\section{Latar Belakang Masalah}

Bawang merah merupakan salah satu komoditi sayuran unggulan yang sejak lama telah dibudidayakan oleh petani Indonesia. Kebutuhan masyarakat terhadap bawang merah terus meningkat karena produk ini sering digunakan di hampir semua masakan. Bawang merah dikenal sebagai bahan bumbu masakan dan bahan obat untuk penyakit tertentu sehingga melekat identitasnya sebagai tanaman rempah dan obat. 
Pengelolaan pada sektor pertanian dengan penanaman bibit bawang merah di Desa Sajen merupakan salah satu strategi untuk pengembangan dan peningkatan kesejahteraan petani. Di beberapa waktu tertentu ketersediaan bawang merah yang kurang dengan permintaan yang cukup tinggi sehingga mengakibatkan melambungnya harga. Potensi inilah yang menjadikan nilai tambah dan kesempatan terbuka bagi petani sayuran sebagai produsen untuk meraup keuntungan. Desa Sajen merupakan salah satu penghasil bawang merah di Kabupaten Mojokerto yang konsisten dengan produksinya dan menyuplai ke beberapa daerah.

Desa Sajen merupakan salah satu desa yang memiliki potensi alam yang subur. Hal ini membuat beberapa tanaman mampu hidup dengan baik, seperti sayur-sayuran, buah-buahan serta satu komoditas tanaman holtikultura yakni tanaman bawang merah juga dapat hidup di sana. Mayoritas masyarakat Desa Sajen berprofesi sebagai seorang petani dan pekebun.

Berdasarkan rantai pasokan, para petani sering menjualnya kepada para tengkulak sehingga hal ini berpengaruh terhadap keuntungan yang diperolehnya. Para pedagang besar jarang sekali mencari bawang merah langsung ke petani pasti selalu membeli di tengkulak karena skalanya juga besar jadi lebih cepat dan mudah bila membeli melalui tengkulak. Hal ini mengakibatkan efesiensi yang tidak tercapai maksimal sebagai akibat dari saluran pemasaran yang kurang optimal.

Masalah lain yang dihadapi oleh para petani adalah sering terjadi perubahan harga. Ketidakstabilan harga ini dapat menyebabkan kerugian bagi petani karena murahnya harga hasil produksi ternyata, berbanding terbalik dengan tingginya biaya produksinya. Selain itu petani pun sering mengeluhkan tentang bibit dan pupuk yang relatif mahal. Ancaman lainnya pun yang akan memberikan dampak terhadap kesejahteraan petani bawang merah adalah adanya impor bawang merah.

Peran pemerintah diperlukan secara aktif untuk menetapkan skema harga hingga proses distribusi serta turut menjamin kualitas produk - produk pertanian. Di antaranya, penyediaan pupuk sekaligus bibit yang baik. Sektor ini pun memerlukan pelatihan dan pendampingan karena bila tidak mendapatkan perhatian khusus dan intensif maka hasil produksinya dipastikan tidak akan bagus. Selain itu pemerintah harus memastikan untuk produksi bawang merah yang dihasilkan di desa dapat memiliki daya saing karena pasar bawang merah sangat besar serta produk turunannya juga cukup banyak.

Berdasarkan uraian tersebut maka penulis tertarik untuk menyusun strategi pengembangan usahatani bawang merah di Desa Desa Sajen, Kecamatan Pacet, Kabupaten Mojokerto dengan menggunakan analisis SWOT.

\section{KAJIAN PUSTAKA}

\section{Strategi}

Strategi merupakan hal penting bagi kelangsungan hidup dari suatu komunitas untuk mencapai sasaran atau tujuan bersama yang efektif dan efisien. Suatu komunitas sosial harus dapat menghadapi setiap masalahmasalah atau hambatan yang datang dari dalam maupun dari luar lingkungan. Strategi merupakan alat untuk mencapai tujuan, dalam pengembangannya konsep mengenai strategi harus terus memiliki perkembangan dan setiap orang mempunyai pendapat atau definisi yang berbeda mengenai strategi. Menurut David (2011) strategi adalah sarana bersama dengan tujuan jangka panjang yang hendak dicapai. Strategi adalah aksi potensial yang membutuhkan keputusan sumber daya dalam jumlah besar. Rangkuti (2013) berpendapat bahwa strategi adalah perencanaan induk yang komprehensif, yang menjelaskan bagaimana pihak tertentu akan mencapai semua tujuan yang telah ditetapkan berdasarkan misi yang telah ditetapkan sebelumnya. Menurut Stoner et al. (2005), konsep strategi dapat didefinisikan berdasarkan dua perspektif yang berbeda yaitu : (1) dari perspektif apa suatu organisasi ingin dilakukan (intens to do) dan (2) dari perspektif apa yang organisasi akhirnya lakukan (eventually does). Jadi strategi adalah sebuah tindakan aksi atau kegiatan untuk mencapai sasaran atau tujuan yang telah ditetapkan. Manajemen strategis menurut Pearce dan 
Robinson (2008) adalah sekumpulan keputusan dan tindakan yang merupakan hasil dari formula dan implementasi dari rencana yang telah didisain untuk mencapai tujuan bersama. Hasil penelitian ini merupakan bahan atau informasi dari pengambilan keputusan strategik yang mungkin bermanfaat bagi penetapan kebijakan bagi masyarakat Desa Sajen.

\section{Kesejahteraan}

Sukoco (1991) mendefinisikan kesejahteraan secara sosial sebagai kegiatan-kegiatan yang terorganisasi dengan tujuan meningkatkan kesejahteraan dari segi sosial melalui pemberian bantuan kepada orang untuk memenuhi kebutuhan-kebutuhan di dalam beberapa bidang seperti kehidupan keluarga dan anak, kesehatan,penyesuaian sosial, waktu senggang, standar-standar kehidupan, dan hubungan-hubungan sosial. Pelayanan kesejahteraan sosial memberi perhatian utama terhadap individu-individu, kelompok-kelompok, komunitas-komunitas, dan kesatuan-kesatuan penduduk yang lebih luas; pelayanan ini mencakup pemeliharaan atau perawatan, penyembuhan dan pencegahan. Dengan demikian tercapainya kesejahteraan sosial ditunjukkan dari sistem yang terorganisasi dari pelayanan-pelayanan sosial dan lembaga-lembaga, yang bermaksud untuk membantu individu-individu dan kelompok agar mencapai standar kehidupan dan kesehatan yang memuaskan, serta hubungan perorangan dan sosial yang memungkinkan mereka mengembangkan segenap kemampuan dan meningkatkan kesejahteraan petani selaras dengan kebutuhan-kebutuhan keluarga maupun masyarakat.

Ada keterkaitan yang erat antara pendapatan, faktor produksi dan tingkat kesejahteraan suatu rumah tangga. Menurut Soekartawi (2002) perubahan tingkat pendapatan akan mempengaruhi banyaknya barang yang akan dikonsumsi, pada tingkat pendapatan rumah tangga yang rendah, maka pengeluaran rumah tangganya lebih besar dari pendapatannya. Hal ini berarti pengeluaran konsumsi bukan hanya dibiayai oleh pendapatan mereka saja, tetapi juga dari sumber lain seperti tabungan yang dimiliki, penjualan harta benda, atau dari pinjaman. Semakin tinggi tingkat pendapatannya maka konsumsi yang dilakukan rumah tangga akan semakin besar pula. Bahkan sering kali sering dijumpai dengan bertambahnya pendapatan, maka barang yang dikonsumsi bukan hanya bertambah akan tetapi kualitas barang yang diminta pun bertambah.

Pendapatan diperoleh dari profesi yang dijalankan oleh anggota rumah tangga terutama kepala rumah tangga. Salah satu bentuk profesi adalah petani. Dengan menjalankan usahatani diharapkan dapat meningkatkan kesejahteraan rumah tangga dan sosial secara umum di suatu daerah.

Prospek usahatani bawang merah berpola agribisnis cukup cerah, bahkan dalam rangka pelaksanaan otonomi daerah, bawang merah diharapkan menjadi komoditas unggulan sebagai sumber pertumbuhan ekonomi baru dari sektor pertanian. Pertumbuhan ekonomi dapat mendorong terjadinya perubahan pola konsumsi masyarakat. Selain itu dengan adanya perubahan pola konsumsi masyarakat juga akan memacu permintaan terhadap produk-produk pangan atau bahan baku yang sejenisnya semakin beragam. Keadaan tersebut dapat menyebabkan berkembangnya segmen-segmen konsumen tertentu terhadap permintaan produk sayuran yang bersifat spesifik, termasuk prospek pemasaran komoditas bawang merah (Hendro, 2001).

\section{Bawang Merah}

Komoditas aneka bawang telah menjadi salah satu komoditas hortikultura yang penting dan sensitif terhadap aspek sosial, ekonomi dan politikdi I ndonesia. Bawang merah (Allium cepa var oggregatum Sin Allium ascalonicum). Dalam sistematika tumbuh-tumbuhan (taksonomi), kedudukan tanaman bawang merah diklasifikasikan sebagai berikut: 
Kingdom: Plantae (Tumbuhan)

Subkingdom: Tracheobionta (Tumbuhan dengan pembuluh)

Super Divisi: Spermatophyta (Menghasilkan bebijian)

Divisi: Magnoliophyta (Tumbuhan dengan bunga)

Kelas: Liliopsida (berkeping satu atau monokotil)

Sub Kelas: Liliidae

Ordo: Liliales

Famili: Liliaceae (suku bawang-bawangan)

Genus: Allium

Spesies: Allium cepa var oggregatum Sin Allium ascalonicum.

Pemanfaatan bawang merah sebagai bahan pangan didukung oleh zat gizi yang terkandung didalamnya. Menurut catatan Departemen Kesehatan Republik Indonesia, kandungan gizi dalam $100 \mathrm{~g}$ umbi baw ang merah meliputi 39 kalori, 1,5 g protein, 0,3 g lemak, 0,2 g karbohidrat, $36 \mathrm{mg}$ kalsium, $40 \mathrm{mg}$ fosfor, 0,8 $\mathrm{mg}$ zat besi, 0,03 $\mathrm{mg}$ vitamin B1, $2 \mathrm{mg}$ vitamin $\mathrm{C}$, dan $88 \mathrm{~g}$ air. Bawang merah dimanfaatkan sebagai bahan pangan dalam bentuk segar, bumbu masakan, atau bentuk bahan kering.

\section{METODE PENELITIAN}

Lokasi penelitian ditetapkan penulis secara sengaja atau purposive, yaitu di Desa Sajen, Kecamatan Pacet, Kabupaten Mojokerto yang merupakan daerah yang memiliki potensi hasil produksi bawang merah. Metode penentuan sampel adalah menggunakan metode aksidental (Accidental Sampling), yaitu penentuan sampel berdasarkan orang yang ditemui secara kebetulan atau siapapun yang dipandang peneliti cocok sebagai sumber data. Data yang diperoleh dalam penelitian ini terdiri dari data primer dan data sekunder. Data primer diperoleh dari wawancara langsung dengan para petani dan PPL Pertanian melalui survei ataupun melalui daftar kuesioner yang telah disiapkan. Sedangkan data sekunder diperoleh melalui lembaga, instansi, atau dinas yang terkait dengan penelitian ini seperti Badan Pusat Statistik dan Dinas Pertanian Kabupaten Mojokerto, didukung pula dari sumber di internet, buku maupun instansi terkait yang relevan yang ada di daerah penelitian serta yang berhubungan dengan tujuan penelitian

Analisis terhadap data akan dilakukan melalui analisis deskriptif kuantitatif dan kualitatif. Analisis deskriptif kuantitatif menggunakan matriks IFAS (Internal Factor Analysis Summary) dan EFAS (External Factor Analysis Summary), sedangkan analisis deskriptif kualitatif menggunakan analisis SWOT. Menurut David (2011), penyusunan suatu strategi dilakukan melalui tiga tahapan kerja yaitu: tahap input, tahapan pencocokkan dan tahapan keputusan.

\section{HASIL PENELITIAN DAN PEMBAHASAN}

Langkah awal adalah analisis faktor-faktor internal dan eksternal strategi pengembangan usahatani bawang merah. Faktor-faktor eksternal terdiri dari faktor peluang dan ancaman dari strategi pengembangan agribisnis bawang merah. Faktor-faktor internal terdiri dari faktor kekuatan dan kelemahan dari strategi pengembangan agribisnis bawang merah.

1. Faktor-faktor Internal

Berdasarkan penelitian yang dilakukan diperoleh faktor-faktor internal yang mempengaruhi pengembangan usahatani bawang merah di desa Sajen adalah sebagai berikut : 
a. Kondisi Fisik dan Mutu Bawang Merah. Pertumbuhan tanaman bawang merah akan lebih maksimal pada musim kemaraudikarenakan bawang merah membutuhkan sinar matahari yang cukup yaitu $\pm 70 \%$.

b. Produksi Bawang Merah. Salah satu faktor yang berperan penting dalam pengembangan agribisnis bawang merah adalah produksi bawang merah. Daun umbi bawang merah mulai tumbuh pada umur 2 minggu dan dapat dipanen pada umur 2-2,5 bulan. Frekuensi tanam yang dimiliki oleh petani bawang merah adalah sama yaitu melakukan dua kali penanaman dalam setahun.

c. Pengalaman petani dalam usahatani bawang merah. Petani bawang merah di desa Sajen telah menekuni usahatani bawang merah sejak dini dan menjadi tenaga kerja dalam keluarga (TKDK). Pengalaman selama bertahun-tahun ini sangat membantu dalam pengembangan usahatani bawang merah. Petani yang telah lama menjalankan usahatani bawang merah tentunya memiliki pengalaman yang lebih banyak. Sebagai contoh, para petani telah mengenali jenis hama yang menyerang tanaman bawang merah, meskipun belum semua hama yang merusak tanaman bawang merah tersebut dapat diberantas oleh petani.

d. Penguasaan petani terhadap teknik budidaya bawang merah

e. Luas Lahan. Ada kelemahan terjadinya penurunan luas lahan bawang merah dari tahun ke tahun dikarenakan cuaca dan iklim tidak menentu serta adanya hama pada tanaman bawang merah. Selain itu ada kemungkinan petani bawang merah beralih fungsi lahan yaitu menanam tanaman yang lain.

f. Penggunaan input seperti bibit, pupuk, pestisida dan alat-alat pertanian. Terdapat hanya sebagian kecil petani yang melakukan pemberantasan hama dengan menggunakan pestisida, sebagian lagi tidak menggunakan pestisida karena keterbatasan modal. Pemberian pestisida juga harus tepat dan cepat, arti dari tepat adalah tepat sasaran dan tepat waktu sedangkan cepat adalah cepat dilakukan sehingga hama dan penyakit tidak berkembang dan menular. Pada musim hujan penyakit tanaman bawang merah lebih dominan menyerang dari pada hama. Pada musim hujan dosis fungisida lebih besar dari pada insektisida. Untuk menanggulangi jamur dan bakteri, waktu penyemprotan harus dilakukan pada pagi hari, untuk menanggulangi hama ulat, waktu penyemprotan dilakukan pada pagi hari atau pada sore hari.

g. Modal petani. Sebagian petani yang berusahatani bawang merah di desa Sajen memiliki modal yang terbatas. Petani tersebut tidak dapat melakukan pinjaman kepada bank kerena tidak memiliki jaminan sehingga petani terpaksa mencari sumber dana pinjaman dari warga atau kerabat petani itu sendiri.

h. Benih yang digunakan dan ketersediaan benih unggul

i. Tenaga Kerja. Keberadaan tenaga kerja sebagai salah satu faktor internal dalam pengembangan bawang merah sangatlah penting. Tenaga kerja yang memadai dan berkualitas akan membantu menghasilkan bawang merah yang baik. Di Desa Sajen tersedia sumber daya manusia namun petani tidak memiliki modal yang cukup untuk membayar tenaga kerja. Sebagian besar petani bawang merah di Desa Sajen menggunakan tenaga kerja dalam keluarga (TKDK) sehingga biaya tenaga kerja minimal namun jumlah tenaga kerja tersebut belum cukup terutama pada waktu pengolahan lahan dan penanaman.

2. Faktor Eksternal

Berdasarkan penelitian yang dilakukan diperoleh faktor-faktor eksternal yang mempengaruhi pengembangan usahatani bawang merah di desa Sajen adalah sebagai berikut : 
a. Permintaan Bawang Merah. Permintaan di tingkat Kecamatan Pacet terpenuhi sesuai dengan produksi dalam kecamatan bahkan produksi bawang merah tersebut hingga menyebar keluar kecamatan, terutama kecamatan yang ada di Kabupaten Mojokerto.

b. Harga input rata-rata dan ketersediaan input. Harga input seperti harga pupuk, bibit, pestisida dan obat-obatan di kecamatan ini tidak terlalu mahal atau harga input rata-rata tersebut sama dengan harga pasar atau harga subsidi karena adanya subsidi dari pemerintah. Ketersediaan input pertanian di Kecamatan Pacet tersedia pada waktu yang tepat yaitu saat petani membutuhkannya. Jumlah input tersebut juga mencukupi kebutuhan petani.

c. Harga jual bawang merah di tingkat petani. Perbandingkan harga jual di tingkat petani tidak terlalu jauh dengan harga beli bawang merah di tingkat konsumen.

d. Dukungan pemerintah. Peran pemerintah khususnya dalam permodalan petani sangatlah penting, dimana pemerintah memberikan berbagai bantuan seperti subsidi pupuk, bantuan bibit unggul dan Kredit Usaha Rakyat (KUR). Hal ini diharapkan dapat membantu para petani yang memiliki keterbatasan terhadap modal.

e. Infrastruktur dan sarana pendukung agroindustri. Gudang penyimpanan bawang merah merupakan bagian penting dalam usahatani bawang merah. Selama ini petani mengeringkan bawang yang telah dipanen dengan cara menggantungkan bawang merah beserta daunnya di atap rumah petani itu sendiri. Prasarana transportasi merupakan bagian penting agar mudah mengakses areal usahatani dan areal pasar. Agroindustri meliputi industri pengolahan, industri peralatan dan mesin pertanian serta industri jasa pertanian. Salah satu tujuan utama agroindustri adalah meningkatkan nilai tambah produk pertanian melalui kegiatan pengolahan atau transformasi hasil pertanian.

f. Dukungan tenaga pendamping (penyuluh pertanian). Sebagian besar petani memperoleh pengetahuan usahatani bawang merah secara otodidak dimana pengetahuan itu diwariskan turun-temurun. Petani seharusnya dapat mengikuti dan mengetahui informasi terkini mengenai teknik budidaya, bibit unggul, mesin-mesin pertanian, panen, penanganan pasca panen ataupun informasi pasar agar tidak kekurangan berbagai informasi penting. Untuk itu, peran tenaga pendamping atau penyuluh pertanian sangat dibutuhkan untuk membimbing petani menjalankan usahatani bawang merah.

g. Posisi tawar petani cenderung masih tergolong lemah. Petani menjual ke tengkulak dan menerima pembayaran berupa uang tunai yang secara langsung dibayar pada saat transaksi. Harga jual dominan ditentukan oleh tengkulak. Posisi tawar petani yang lemah dapat disebabkan oleh kurangnya atau terbatasnya akses petani terhadap informasi harga bagi produk yang akandipasarkan.

h. Akses Pasar terhambat karena lebih sering menjual ke tengkulak dibandingkan pedagang besar.

Setelah semua faktor internal dan eksternal sudah diketahui maka selanjutnya dapat mengetahui kondisi atau keadaan usahatani bawang merah di desa Sajen saat ini dengan melihat Gambar berikut ini.

Apabila matriks evaluasi faktor internal digabungkan dengan matriks evaluasi faktor eksternal maka dapat diketahui posisi strategi pengembangan agribisnis bawang merah. Posisi strategi pengembangan agribisnis dianalisis menggunakan matriks posisi sehingga akan menghasilkan titik kordinat (x,y). Nilai x merupakan selisih faktor internal (kekuatan-kelemahan) dan nilai y merupakan selisih faktor eksternal (peluangancaman). Dari Matriks IFAS dan EFAS diketahui nilai $\mathrm{x}$ adalah 0,49 dan nilai y adalah 0,57. Posisi koordinat gabungan matriks evaluasi faktor internal dan eksternal ini dapat dilihat pada Gambar 1. 
Dari Gambar 1 menunjukkan posisi strategi pengembangan usahatani bawang merah terletak pada kuadran I. Kuadran I merupakan kuadran yang dibatasi oleh sumbu $\mathrm{x}$ dan sumbu y yang keduanya bertanda positif dan alternatif strategi yang dianjurkan adalah strategi agresif (aggressive strategy) yaitu strategi SO (Strenght-Opportunity), dimana kuadran ini mempunyai posisi yang paling menguntungkan karena kekuatan dan peluang dalam matriks posisi tersebut adalah baik sehingga dengan kekuatan yang dimiliki usahatani dimungkinkan untuk memanfaatkan peluang usahatani yang ada dan mengembangkannya.

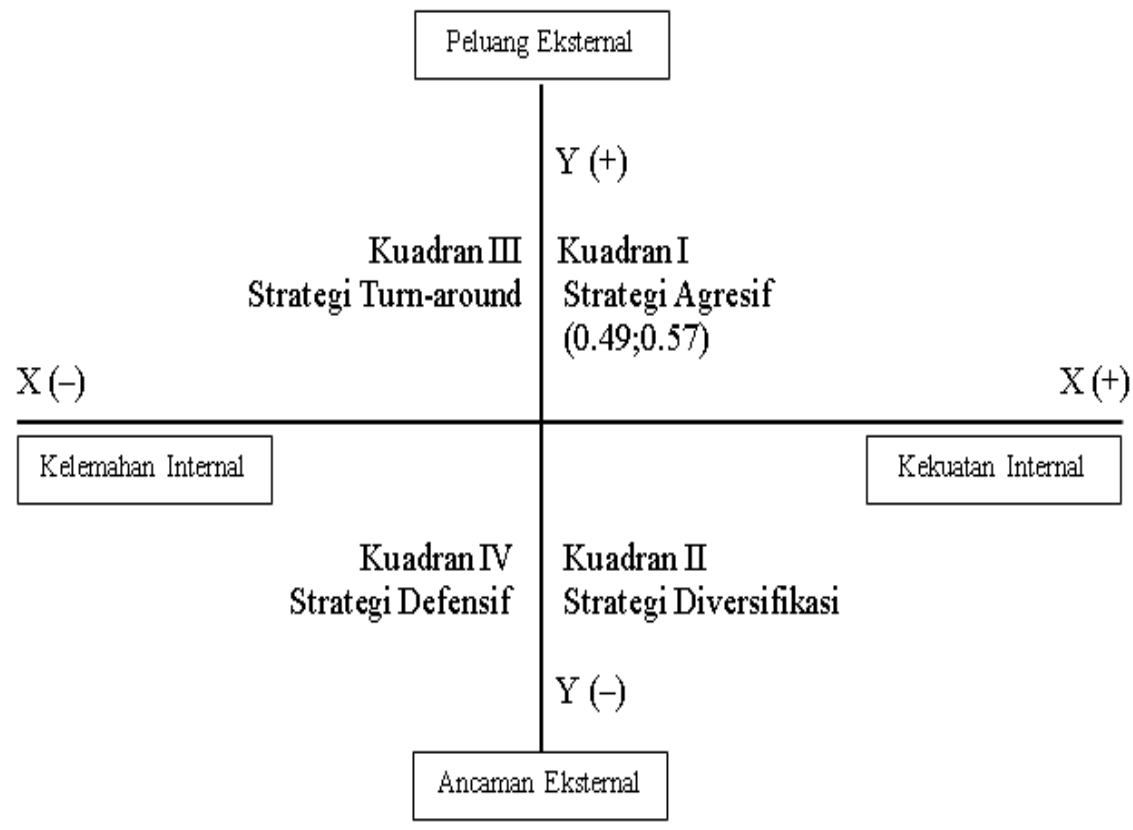

Gambar 1 Matriks Posisi Strategi Pengembangan Bawang Merahdi Desa Sajen

Sumber : diolah oleh penulis, 2018

Strategi pengembangan usahatani bawang merah di desa Sajen berada di kuadran I, artinya bawang merah tersebut memiliki faktor-faktor kekuatan dalam kondisi yang baik namun petani bawang merah belum memanfaatkan peluang yang ada sehingga bawang merah belum berkembang. Untuk itu diperlukan sterategi agresif yaitu melakukan ekspansi dan meningkatkan pertumbuhan secara maksimal dengan memanfaatkan peluang dan kekuatan yang ada (strength-opportunities strategy).

Tahap selanjutnya adalah menentukan alternatif strategi pengembangan usahatani bawang merah.. Matriks SWOT disusun berdasarkan faktor-faktor internal kekuatan (strength), kelemahan (weakness) dan faktorfaktor eksternal yaitu peluang (opportunity) dan ancaman (threat). Berdasarkan matriks SWOT maka dapat diperoleh empat strategi utama yaitu strategi strength-opportunities (SO), strategi weakness-opportunities (WO), strategi strength-threat (ST) dan strategi weakness-threat (WT). Strategi tersebut diuraikan berikut ini.

1. Staregi SO. Strategi yang dilaksanakan dalam pengembangan agribisnis bawang merah antara kekuatan dan peluang (strengths and opportunities) adalah :

a. memanfaatkan dukungan pemerintah dalam menyalurkan modal untuk memperluas lahan usahatani bawang merah.

b. memanfaatkan harga input rata-rata dan ketersediaan input untuk meningkatkan kondisi fisik dan mutu bawang merah

c. memanfaatkan akses pasar, permintaan bawang merah dan harga jual di tingkat petani untuk meningkatkan jumlah produksi bawang merah.

2. Strategi WO. Strategi yang dilaksanakan dalam pengembangan agribisnis bawang merah antara kelemahan dan peluang (weakness and opportunities) adalah : 
a. memanfaatkan dukungan pemerintah dalam bantuan modal petani.

b. memanfaatkan permintaan bawang merah dalam meningkatkan modal petani

c. memanfaatkan harga input rata-rata agar petani lebih efektif dalam penggunaan jumlah input.

d. memanfaatkan harga jual bawang merah untuk meningkatkan penguasaan tenaga kerja yang digunakan terhadap teknik budidaya

3. Strategi ST. Strategi yang dilaksanakan dalam pengembangan agribisnis bawang merah antara kelemahan dan peluang (strengths and threats) adalah :

a. memperbaiki infrastruktur dan sarana pendukung agroindustri sehingga dapat meningkatkan produksi bawang merah.

b. meningkatkan pengetahuan seluruh tenaga pendamping (penyuluh pertanian) untuk meningkatkan kualitas kondisi fisik dan mutu bawang merah.

c. memanfaatkan pengalaman petani dalam usahatani bawang merah untuk mempertahankan posisi tawar petani.

4. Strategi WT. Strategi yang dilaksanakan dalam pengembangan agribisnis bawang merah antara kekuatan dan peluang (weakness and threats) adalah :

a. meningkatkan infrastruktur dan sarana pendukung agroindustri sebagai penunjang tenaga kerja.

b. meningkatkan kemampuan tenaga pendamping (penyuluh pertanian) untuk meningkatkan penguasaan petani terhadap teknik budidaya.

c. meningkatkan penguasaan petani terhadap budidaya untuk mempertahankan posisi tawar.

Berdasarkan uraian tersebut strategi dengan metode ini menghasilkan strategi yang paling optimal. Strategistrategi ini mengarah pada upaya menciptakan keunggulan bersaing (competitive adventage) yang bertujuan agar usahatani bawang merah dapat bertahan dan berkembang dalam kurun waktu yang relatif lama.

\section{PENUTUP}

\section{Kesimpulan}

Dari hasil analisis hasil penelitian dan pembahasannya, diperoleh hal-hal yang menjadi hal pokok untuk disimpulkan sebagai penutup di laporan penelitian ini. Berikut adalah hasil penelitian ini. Faktor internal kekuatan dalam agribisnis usahatani bawang merah di desa Sajen yaitu memililki kondisi fisik dan mutu bawang merah yang baik, produksi bawang merah yang mencukupi permintaan konsumen di Kecamatan Pacet, luas lahan, benih unggul yang digunakan dan ketersediaan benih. Faktor internal kelemahan yaitu petani masih kurang ahli dalam penguasaan teknik budidaya, minimnya modal petani, tenaga yang digunakan kurang berkualitas dan jumlah penggunaan input masih belum sesuai dengan rekomendasi Dinas Pertanian. Faktor eksternal peluang yaitu permintaan bawang merah terpenuhi, harga input rata-rata sesuai dengan harga pasar dan tersedianya input tersebut, adanya dukungan dari pemerintah, harga jual di tingkat petani tinggi dan mudahnya akses pasar. Faktor eksternal ancaman yaitu kurang memadainya infrastruktur dan sarana pendukung agroindustri, posisi tawar berada pada pedagang besar dan kurangnya kemampuan penyuluh pertanian dalam agribisnis usahatani bawang merah.

Strategi alternatif yang digunakan adalah strategi SO (strengths and opportunities) yaitu memanfaatkan dukungan yang ada agar petani memperoleh bantuan benih berkualitas, memanfaatkan dukungan pemerintah untuk menyalurkan modal untuk memperluas lahan usahatani bawang merah, memanfaatkan harga input rata-rata dan ketersediaan input untuk meningkatkan kondisi fisik dan mutu bawang merah, memanfaatkan akses pasar, permintaan bawang merah dan harga jual di tingkat petani untuk meningkatkan jumlah produksi bawang merah, menambah pengalaman petani dalam agribisnis usahatani bawang merah. 


\section{Saran}

Berdasarkan kesimpulan tersebut maka saran yang dapat penulis berikan untuk meningkatkan kesejahteraan petani bawang merah di Desa Sajen, Kecamatan Pacet, Kabupaten Mojokerto adalah memanfaatkan sumber daya alam yang ada di desa Sajen, khususnya untuk bidang pertanian dan perkebunan. Kondisi alam yang sangat subur dan memungkinkan berbagai macam tanaman dapat tumbuh dengan subur.

Petani agar mempertahankan kualitas bawang merah dengan cara mengontrol tanaman secara rutin dan melakukan pengendalian hama dan penyakit tanaman secara terpadu, memperhatikan waktu panen, dan mengantisipasi adanya iklim yang tidak menentu terutama curah hujan yang cukup tinggi dengan cara meninggikan bedengan. Hal ini akan membantu menghasilkan bawang merah yang berkualitas yang mampu bersaing di pasar.

Selain itu juga membuka akses ke jalur permodalan bagi petani dan pelaku agribisnis, seperti melakukan kembali kerja sama dengan beberapa pemilik modal atau pihak perbankan. Kepada Pemerintah Daerah melalui institusi terkait hendaknya menyusun kebijakan yang mendukung pengembangan agribisnis bawang merah berupa bantuan pemodalan, pelatihan dan pembinaan secara berkelanjutan, pembangunan dan peningkatan kualitas sarana dan infrastruktur serta kebijakan mendukung posisi tawar petani dan harga jual bawang merah di tingkat petani. Dinas pertanian kabupaten terlibat dalam penyediaan bibit bawang merah sampai kepada pemberian pelatihan budidaya dan manajemen kelompok program pengembangan bawang merah. Dinas pertanian juga melibatkan diri untuk berpartisipasi menyediakan lumbung penyimpanan hasil panen bawang merah. Petani diberikan pelatihan untuk mengolah hasil panen lanjutan seperti bawang goreng, tepung bawang merah, dan kerupuk bawang merah.

Kepada peneliti selanjutnya disarankan untuk melakukan penelitian lebih lanjut mengenai bawang merah khususnya mengenai tata niaga, pemasaran bawang merah, pengolahan bawang merah dan membandingkan bawang merah lokal dengan bawang merah non lokal.

\section{DAFTAR PUSTAKA}

David, Fred.R. 2011. Manajemen Strategis: Konsep-Konsep. Edisi Duabelas. Jakarta : Salemba Empat Hendro, Sunarjono. 2001. Budidaya Bawang Merah, Bandung : Sinar Baru Algensindo

Pitojo, S. 2001. Benih Bawang Merah. Yogyakarta : Kanisius.

Pearce, John A, Richard B. Robinson, 2008. Strategic Management: Formulation, Implementation and Control, Edisi 10, Terjemahan oleh Yanivi Bachtiar dan Christine, 2008, Jakarta : Salemba Empat.

Rangkuti, Freddy. 2013. Analisis SWOT Teknik Membedah Kasus Bisnis. Jakarta : PT Gramedia Pustaka Utama

Rahayu, E. dan Berlian, N. 2007. Bawang Merah. Jakarta : Penebar Swadaya.

Rangkuti, F. 2005. Analisis SWOT Teknik Membedah Kasus Bisnis. Jakarta : PT Gramedia Pustaka Utama

Rukmana, Rahmat. 2010. Bawang Merah dari Biji, Teknik Budiaya dan Prospek Agrobisnis, Semarang : Aneka Ilmu

Singgih, Wibowo. 2008. Budidaya Bawang Merah, Bawang Putih dan Bawang Bombay, Jakarta : Penebar Swadaya

Soekartawi, 2002. Prinsip Dasar Ekonomi Pertanian. Teori dan Aplikasi. Jakarta : Raja Grafindo Persada. Jakarta. 
Stoner, James A.F, Freeman, R. Edward, Gilbert JR, Daniel. R, 2005. Manajemen, Jilid 1, PT Bhuana Ilmu Populer

Sukoco, Dwi Heru. 1991. Profesi Pekerjaan Sosial. Bandung : Kompma STKS

Singgih, Wibowo. 2008. Budidaya Bawang Merah, Bawang Putih dan Bawang Bombay. Jakarta : Penebar Swadaya 